\title{
Blended Sewage Sludge-Palm Kernel Expeller to Enhance the Palatability of Black Soldier Fly Larvae for Biodiesel Production
}

\author{
Ratchaprapa Raksasat ${ }^{1}$, Kunlanan Kiatkittipong ${ }^{2, *}\left(\mathbb{D}\right.$, Worapon Kiatkittipong ${ }^{3}{ }^{\oplus}$, Chung Yiin Wong ${ }^{1}{ }^{(0}$, \\ Man Kee Lam ${ }^{4}$, Yeek Chia Ho ${ }^{5} \mathbb{D}$, Wen Da Oh ${ }^{6}$, I Wayan Koko Suryawan ${ }^{7}$ (D) and Jun Wei Lim ${ }^{1, * \mathbb{C}}$
}

1 Department of Fundamental and Applied Sciences, HICoE-Centre for Biofuel and Biochemical Research, Institute of Self-Sustainable Building, Universiti Teknologi PETRONAS, Seri Iskandar 32610, Perak Darul Ridzuan, Malaysia; ratchaprapa_20000290@utp.edu.my (R.R.); johnsonwcy@gmail.com (C.Y.W.)

2 Department of Chemical Engineering, Faculty of Engineering, King Mongkut's Institute of Technology Ladkrabang, Bangkok 10520, Thailand

3 Department of Chemical Engineering, Faculty of Engineering and Industrial Technology, Silpakorn University, Nakhon Pathom 73000, Thailand; kiatkittipong_w@su.ac.th

4 Department of Chemical Engineering, HICoE-Centre for Biofuel and Biochemical Research, Institute of Self-Sustainable Building, Universiti Teknologi PETRONAS, Seri Iskandar 32610, Perak Darul Ridzuan, Malaysia; lam.mankee@utp.edu.my

5 Department of Civil and Environmental Engineering, Centre of Urban Resource Sustainability, Institute of Self-Sustainable Building, Universiti Teknologi PETRONAS, Seri Iskandar 32610, Perak Darul Ridzuan, Malaysia; yeekchia.ho@utp.edu.my

6 School of Chemical Sciences, Universiti Sains Malaysia, Penang 11800, Malaysia; ohwenda@usm.my

7 Faculty of Infrastructure Planning, Department of Environmental Engineering, Universitas Pertamina, Komplek Universitas Pertamina, Jalan Sinabung II, Terusan Simprug, Jakarta 12220, Indonesia; i.suryawan@universitaspertamina.ac.id

updates

Citation: Raksasat, R.; Kiatkittipong, K.; Kiatkittipong, W.; Wong, C.Y.; Lam, M.K.; Ho, Y.C.; Oh, W.D.; Suryawan, IW.K.; Lim, J.W. Blended Sewage Sludge-Palm Kernel Expeller to Enhance the Palatability of Black Soldier Fly Larvae for Biodiesel Production. Processes 2021, 9, 297. https://doi.org/10.3390/pr9020297

\section{Academic Editor:}

Gurutze Arzamendi

Received: 25 December 2020

Accepted: 27 January 2021

Published: 4 February 2021

Publisher's Note: MDPI stays neutral with regard to jurisdictional claims in published maps and institutional affiliations.

Copyright: (c) 2021 by the authors Licensee MDPI, Basel, Switzerland. This article is an open access article distributed under the terms and conditions of the Creative Commons Attribution (CC BY) license (https:// creativecommons.org/licenses/by/ $4.0 /)$
* Correspondence: kunlanan.kia@kmitl.ac.th (K.K.); junwei.lim@utp.edu.my (J.W.L.)

\begin{abstract}
Black soldier fly larvae (BSFL) have been employed for valorizing organic waste materials as the larvae are able to consume organic waste and transform it into valuable larval biomass. In this study, BSFL were found to potentially reduce blended sewage sludge. The addition of palm kernel expeller (PKE) fortified the protein and lipid content in blended sewage sludge substrates, leading to larval growth enhancement. In addition, the larval weight also influenced the lipid yield and fatty acid methyl ester (FAME) profile. However, the optimum ratio of sewage sludge to PKE had to be determined as excess PKE content could become a threat to larval growth by contributing to the reduction of non-fiber carbohydrates content in the feed, thereby resulting in the decrease in lipid yield and FAME content. In this work, a sewage sludge to PKE ratio of 2:3 proffered the highest larval weight gained at $46.99 \pm 2.09 \mathrm{mg} /$ larva. Meanwhile, a proportion of 3:2 of sewage sludge to PKE was able provide the highest lipid yield of $17 \pm 1.77 \%$. Furthermore, the FAME profile revealed the presence of a significant amount of saturated and monosaturated fatty acids, indicating a good quality biodiesel. Thus, BSFL-based biodiesel fed with blended sewage sludge and PKE could be utilized for producing a high quality biodiesel. However, further improvement on the amount of lipid yield and FAME content should be further investigated.
\end{abstract}

Keywords: black soldier fly larvae; palm kernel expeller; sewage sludge; lipid; biodiesel

\section{Introduction}

The increase in environmental concerns, especially climate change, has become an awareness issue for industries at the present time to reduce the amount of greenhouse gases emitted into atmosphere [1,2]. Combustion of fossil fuels stemming from myriad human activities, such as transportation, coal-fired power plants, and large industries, can pollute the air by producing greenhouse gases, particularly nitrogen oxides and ammonia. The presence of excessive nitrogen oxides in the atmosphere can contribute to environmental problems via the formation of smog and acid rain [3]. Thus, the utilization of biodiesel 
instead of fossil fuels is considered clean in addition to its renewability, since biodiesel can be generated from biomass materials [1]. According to the United States Environmental Protection Agency, biodiesel can reduce the emission of greenhouse gases by $86 \%$ [4]. The increasing biodiesel consumption worldwide, i.e., approximately 429.9 thousand barrels per day, has led to the investigation of sustainable raw materials to produce biodiesel [5]. The production of biodiesel from edible crops, which were regarded as the first generation of biodiesel feedstock classification, can result in a shortfall of food sources. Lignocellulosic biomass has been studied for producing the second generation of biodiesel. However, advanced equipment is needed for the operational process, leading to high investment cost [6]. Although the third generation of biofuel has been investigated to replace the lignocellulosic biomass for producing biodiesel from microalgae and cyanobacteria, an expensive harvesting cost is inevitably required. Although these microorganisms contain a high level of lipid contents, i.e., over $75 \%$ in microalgae, ample time and intensive energy are needed for handling a large volume of microalgal feedstock [7-9]. To overcome the challenges, lipid derived from insect larvae has become an attractive source for biodiesel production as the larvae are considered an economical feedstock, easily grown, and can bioconvert organic waste materials into its biomass through biotransformation process [10-13].

Insect larvae can consume organic wastes, such as food waste, fruit and vegetable waste, animal manures, and sludge, then bio-convert the wastes into more valuable larval biomass for further applications [14-17]. Lipid from insects in the form of fat is a predominant biomass composition that has been studied to produce a sustainable biofuel [11]. Larval lipid is stored in its body to be used during the non-feeding period of the larval lifecycle $[9,18]$. Among the various insect species such as flesh fly, superworm, mealworm beetle, housefly, latrine blowfly, soldier fly, and ants, Hermetia illucens larvae, or black soldier fly larvae (BSFL), are commonly selected for producing biodiesel since BSFL can valorize a variety of organic wastes; contain a high level of lipid content (around 50\%); the adults are not a pest; they can cope with a wide range of environmental conditions, e.g., $\mathrm{pH}$, temperature, and humidity; and they need less workforce for mass rearing [19-28]. The fatty acid profile from BSFL lipid had been found mainly comprising of C12:0 (38.43 wt $\%)$, C16:1 (15.71 wt\%), and C14:0 (12.33 wt\%), which are the essential compositions in biodiesel. Addtionally, the high C12:0 in fatty acid methyl esters (FAMEs) of biodiesel could contribute to the low density and kinematic viscosity, and high oxidation stability of the produced biodiesel [29,30]. Leong et al. [31] confirmed that the FAMEs derived from extracted lipid of BSFL were mainly composed of $\mathrm{C} 12: 0$ at $76.1 \%, 58.3 \%$, and $48.1 \%$ when individually fed with fruit waste, sewage sludge, and palm decanter, respectively.

Sewage sludge, an organic waste from wastewater treatment plants, is expected to continue growing worldwide due to the rising number of households connected to central treatment plants [32]. The presence of untreated sewage sludge can afflict the surrounding environments since the sewage sludge's general compositions are recalcitrant organic pollutants. Furthermore, sewage sludge is also laden with degradable organic compounds, macronutrients, micronutrients, non-essential trace metals, organic micro-pollutants, microorganisms, and pathogens, which can cause difficulties for the disposal [33-35]. A proper management of sewage sludge is required, as the mismanagement of sewage sludge via agricultural use, landfill, and incineration have afflicted human health and environments [36]. Valorization of sewage sludge by BSFL is perceived as economical and environmentally friendly, since the larvae have a potential to assimilate the organic sewage sludge. Moreover, the lipid extracted from larval fat to produce biodiesel through transesterification was proved not to be contaminated with heavy metals from sewage sludge $[37,38]$. However, the sewage sludge's improper nutritional properties can retard larval development, such as slow growing time or small prepupal size impinging its mortality [17,31]. Thus, blending sewage sludge with low-cost and nutritionally rich feeding substrate was considered to improve the nutritional constituent in the feeding substrate, prior to administering it to BSFL. In this work, the challenge of sewage sludge management via exploiting BSFL to assimilate and produce more valuable chemicals, i.e., a 
good quality BSFL-base biodiesel, was materialized. Accordingly, the aim was to use palm kernel expeller (PKE) as a nutritional substrate to blend with sewage sludge in improving the feeding substrate nutrition for enhancing larval development and larval biodiesel quality. This low-cost agrifeed comprises $14.5-19.6 \%$ dry matter of crude protein, which is a significant nutrient for spurring overall animal growth [39]. However, PKE alone had been found retarding BSFL growth, as the presence of excessive protein would create a deleterious environment for the growing larvae. Thus, it was evidenced that blending it with sewage sludge could synergistically enrich the substrate alimentation for the rearing of BSFL, targeting the production of lipid for the conversion into BSFL-based biodiesel. Upon completing the research, the projection for large-scale production of BSFL-based biodiesel was also unveiled, paving the way for its real application.

\section{Materials and Methods}

\subsection{Preparation of Blended Substrates}

The dewater sewage sludge and palm kernel expeller (PKE) were collected from the local municipal wastewater treatment plant and palm oil mill, respectively. The collected dewater sewage sludge possessed an initial moisture content of approximately $90 \%$, while the PKE was already in the powdered and dry form. The sewage sludge was blended with PKE at various ratios: namely, sewage sludge to PKE at 5:0, 4:1, 3:2, 2:3, 1:4, and 0:5 (signified as G1, G2, G3, G4, G5, and control, respectively). The total dry weight for each blended substrate was fixed at $10 \mathrm{~g}$; for example, G2 was composed of $8 \mathrm{~g}$ of sewage sludge and $2 \mathrm{~g}$ of PKE, both measured in terms of dry weight. All substrates' moisture content was maintained around $70 \%$ before administering to the BSFL.

\subsection{Experimental Set Up for BSFL Rearing}

Fresh black soldier flies' eggs were bought from MLF Ingredient Sdn Bhd located in Johor, Malaysia. Upon arrival, the eggs were transferred into clean container and left in incubator at $27^{\circ} \mathrm{C}$ until eclosion. The newly hatched BSFL were collected and reared using fresh coconut endosperm waste until 6 days old, prior to the employment for experiments. A total of 206 -day old larvae were then handpicked and reared in a plastic container with the diameter of $8 \mathrm{~cm}$, and height of $10 \mathrm{~cm}$, as well as equipped with perforated lid. The blended feeding substrates at different ratios were individually administrated to each of the 20 BSFL. The rearing period was ended once $80 \%$ of BSFL had reached their 5 th instar stage. The mature BSFL were then harvested via individual separation from the residual feed, washed with distilled water, and deactivated in freezer at $-20^{\circ} \mathrm{C}$ for $10 \mathrm{~min}$ before being dried in an oven at $65^{\circ} \mathrm{C}$ until a constant weight was obtained. The duration of larval rearing from six days old until the day on which they were deactivated, and final total weight of larvae were recorded. The feed residue was also recorded to determine the overall degradation (OD) and waste reduction index (WRI) as presented by Equations (1) and (2), respectively. The larvae's digestibility of consumed feed was represented in terms of efficiency of conversion of digested feed (ECD) as shown in Equation (3). Finally, the metabolism of consumed feed (g) was calculated based on mass balance [15] as shown in Figure 1.

$$
\begin{gathered}
\text { Overall degradation }(\mathrm{OD})=\frac{\text { Total dry feed offered }(\mathrm{g})-\text { Dry residue remained }(\mathrm{g})}{\text { Total dry feed offered }(\mathrm{g})} \times 100 \% \\
\text { Waste reduction index }(\mathrm{WRI})=\frac{\text { Total dry feed offered }(\mathrm{g})-\text { Dry residue remained }(\mathrm{g})}{\text { Rearing duration }(\text { day })} \\
\text { Efficiency of conversion of digested feed }(\mathrm{ECD})=\frac{\text { Larval biomass }(\mathrm{g})}{\text { Total dry feed offered }(\mathrm{g})-\text { Dry residue remained }(\mathrm{g})} \times 100 \%
\end{gathered}
$$




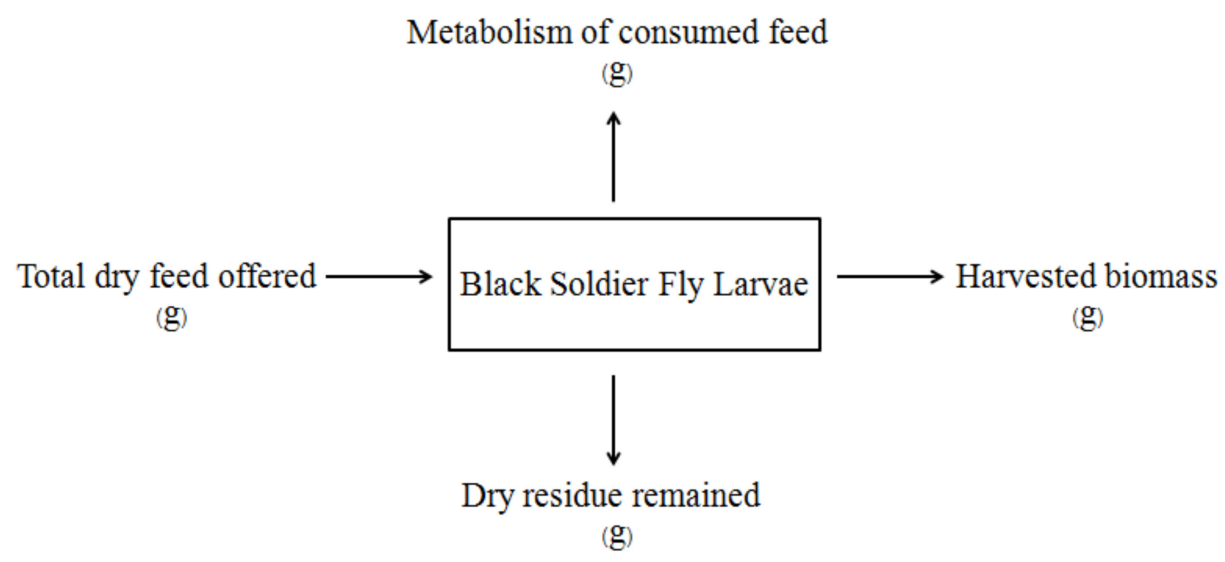

Figure 1. Mass balance model of valorization of blended sewage sludge with palm kernel expeller (PKE) via bioconversion into the biomass of black soldier fly larvae.

\subsection{Lipid Extraction from BSFL Biomass}

The dry larvae were mashed until becoming a homogenized form. A $100 \mathrm{mg}$ of homogenized larval biomass was then introduced to a cylindrical glass bottle with a diameter of $23 \mathrm{~mm}$, and height of $96 \mathrm{~mm}$. A $20 \mathrm{~mL}$ of petroleum ether was then added into the same bottle and mixed on an orbital shaker operated at $300 \mathrm{rpm}$ for $24 \mathrm{~h}$. After that, the mixture of BSFL biomass and petroleum ether was filtrated with a filter paper. The petroleum ether was then evaporated from the filtrate under a blow of compressed air. Finally, the extracted lipid was introduced into an oven at $105^{\circ} \mathrm{C}$ for $30 \mathrm{~min}$ to ensure the leftover moisture was as well evaporated. The lipid yield from prepupae in dry weight basis was then computed by using Equation (4).

$$
\text { Lipid yield }=\frac{\text { Extarcted larval lipid }(\mathrm{mg})}{\text { Homogenized larval biomass }(\mathrm{mg})} \times 100 \%
$$

\subsection{Transesterification of Larval Lipid into BSFL-Based Biodiesel}

The extracted lipid was introduced with $1 \mathrm{~mL}$ of chloroform as a co-solvent to assist the lipid dissolution. A methanol containing $1 \mathrm{wt} \%$ of potassium hydroxide was then added to carry out a base-catalyzed transesterification process. The mixture was heated to $65^{\circ} \mathrm{C}$ by heating mantle and stirred at $200 \mathrm{rpm}$ for $1 \mathrm{~h}$. Once the reaction had finished, the solvent consisting of methanol and chloroform was then evaporated at $70^{\circ} \mathrm{C}$. The fatty acid methyl esters (FAMEs) mixture had with $2 \mathrm{~mL}$ of petroleum ether added, and was washed 2 times with $2 \mathrm{~mL}$ of saline water (10\% sodium chloride in methanol). FAMEs mixture was retrieved by using $1 \mathrm{~mL}$ of petroleum ether and transferred into a pre-weighed glass vial. Petroleum ether was then dried under a compressed air blow. Sample was introduced into oven at $105^{\circ} \mathrm{C}$ for $30 \mathrm{~min}$ to ensure that the residue moisture was completely evaporated. Weight of FAMEs was measured once the glass vial was cooled down to room temperature.

Characterization of the FAME profile of BSFL-derived biodiesel was prepared by adding $1 \mathrm{~mL}$ of methyl heptadecanoate (C17:0) in hexane as an internal standard at the concentration of $1.012 \mathrm{mg} / \mathrm{mL}$ into a pre-weighed FAMEs sample. The FAME profile was analyzed by using the Shimadzu GC-2010 plus (Manufactured by Shimadzu Corporation, Kyoto, Japan) equipped with a flame ionization detector and a polyethylene glycol capillary column BPX-BD20 $(30 \mathrm{~m} \times 0.32 \mathrm{~mm} \times 0.25 \mu \mathrm{m})$. Helium gas was used as a carrier gas, and the inlet was operated in a split mode $(1: 50)$ at a temperature of $250{ }^{\circ} \mathrm{C}$. The column temperature was programmed at the ramping mode. The percentage of FAME composition in BSFL-derived biodiesel was calculated as presented in Equation (5) [40].

$$
\text { FAMEs content }(\%)=\frac{\mathrm{A}_{\mathrm{FAME}}}{\mathrm{A}_{\mathrm{ISTD}}} \times \frac{\mathrm{C}_{\text {ISTD }} \times \mathrm{V}_{\text {ISTD }}}{\mathrm{m}} \times 100 \%
$$


where $A_{F A M E}$ is the peak area of specific FAMEs; $A_{\text {ISTD }}$ is the peak area of internal standard (C17:0); $\mathrm{C}_{\mathrm{ISTD}}$ is the concentration of internal standard (C17:0), which was $1.012 \mathrm{mg} / \mathrm{mL}$; $\mathrm{V}_{\text {ISTD }}$ is the volume of internal standard (C17:0), which was $1.0 \mathrm{~m}$; and $\mathrm{m}$ is the mass of sample used to mix with internal standard (C17:0).

\section{Results and Discussion}

\subsection{Effect of Different Ratios of Blended Sewage Sludge on BSFL Growth}

The growth of BSFL was studied in terms of rearing duration and final larval dry weight when fed with various blended sewage sludge (Figure 2). The larval weight was significantly influenced by the blended feed compositions [15]. In this study, the larval weight was the lowest with G1, i.e., the larvae fed with sewage sludge only $(14.38 \pm 0.34 \mathrm{mg} /$ larva). This could be rationalized by the presence of extracellular polymeric substances formed by bacterial cells as a protective shield to prevent the digestion process by other microorganism colonies. Therefore, similarly, this also hindered the digestion by BSFL in assimilating the nutrients in sewage sludge, leading to the retardation of larval growth $[31,41]$. The larval weight was then found to be increasing when the PKE was blended into sewage sludge in G2 and G3 mediums and reached the highest value, i.e., $46.99 \pm 2.09 \mathrm{mg} /$ larva, in the G4 medium containing sewage sludge to PKE at a ratio of 2:3. As the proportion of PKE increased, it raised the protein content in blended feed, which was vital for larval growth to undergo pupation. The presence of more PKE would fortify the nutritional balance in the larval feed as well as enhance the buffer capacity in facilitating the BSFL digestion process [42-44]. However, the larval weight was noticed to be dropping conspicuously with a further increase in PKE in the G5 medium, primarily due to the presence of excess energy compositions in the feed. The major compositions in PKE were protein (14.4\%), lipid (10\%), and fiber (16\%) [45]. The presence of a high protein level in the blended medium would contribute to a high energy input in BSFLs' diet. Thus, the excess protein content stemming from the increase in PKE proportion could retard the larval growth as too high an energy input from the feed would stimulate the BSFL to execute the detoxification of the proteinogenic nitrogen process within the larval digestion system $[42,46,47]$. Furthermore, the lipid constituent in PKE also offered a good source of metabolizable energy, increasing the energy density of feed to enhance the larval weight $[48,49]$. However, the excess amount of lipid content also could impede the larval development, since the unutilized lipid would hinder the digestion process by BSFL for assimilating nutrients [26]. The excess lipid could retard the fiber digestion process, since it inhibited the microbial activities within the larval digestive tract that are involved in cellulose digestion, thereby further decreasing the larval palatability towards feed $[50,51]$. The presence of high fiber content with the increase in PKE proportion in blended sewage sludge also could be associated with small larval weight since the fiber could not be easily digested and assimilated by the growing BSFL [17].



Figure 2. Effect of different ratios of blended sewage sludge on larval rearing durations and final black soldier fly larvae (BSFL) weights. 
In a similar way, the rearing duration of BSFL was shorter when the amount of the propotion of PKE in the blended feeding substrate increased, i.e., it took 27 days from the larval rearing period for $80 \%$ to emerge from the 5 th instar stage when fed with sewage sludge, but only 13 days whilst using G5 and control mediums. This could be ascribed by the effect of food nutrients on larval weight and rearing duration at the critical developmental stage [52,53]. The limitation of larval development to a defined time until pupation stage is affected by a shift in hormonal level at a critical developmental stage condition $[54,55]$. In addition, the larvae's critical weight, i.e., the larval final weight, was also relatively constant once the larvae had stopped feeding in preparation to enter pupation [56]. The rearing duration required for larvae to reach the critical weight was dependent on the nutrition availability, since the imbalanced nutrients in feed would result in a longer time entailed for feed accumulation to compensate for nutrient deficiency $[52,57,58]$.

Table 1 shows the overall degradation (OD) and waste reduction index (WRI) investigated in the current study to prove the potential of BSFL to valorize solid organic wastes associated with the bioconversion process. The WRI increased with the increase in PKE. Generally, the higher the WRI, the higher the amount of waste being valorized per time period [9]. It was found that the capability of BSFL to valorize organic waste materials via assimilation for growth was dependent on the properties of feed as shown in terms of efficiency of conversion of digested feed (ECD). The optimum ratio of blended feeding substrate could proffer a high conversion of substrate into BSFL biomass. In this study, the ECD was in a range of $1-5 \%$. The ECD values rose up with the increase in PKE and reached the highest in the G4 medium. The lower ECD indicated insufficient nutrition in blended sewage sludge for feeding of BSFL [15]. The ECD was then slightly decreased in the G5 medium, and this could be due to the presence of excess fiber that was difficult to be digested by BSFL [17].

Table 1. Valorization of various blended sewage sludge ratios by BSFL.

\begin{tabular}{ccccccc}
\hline \multirow{2}{*}{ Parameter } & \multicolumn{5}{c}{ Blended Sewage Sludge Medium } \\
\cline { 2 - 6 } & G1 & G2 & G3 & G4 & G5 & Control \\
\hline Overall degradation (\%) & $73.34 \pm 5.41$ & $67.39 \pm 2.68$ & $62.45 \pm 4.31$ & $75.91 \pm 3.30$ & $84.85 \pm 3.03$ & $85.74 \pm 0.20$ \\
Waste reduction index (g/d) & $0.54 \pm 0.04$ & $0.61 \pm 0.02$ & $0.83 \pm 0.06$ & $1.08 \pm 0.05$ & $1.31 \pm 0.05$ & $1.32 \pm 0.00$ \\
Efficiency of conversion of & $1.14 \pm 0.32$ & $1.94 \pm 0.23$ & $2.71 \pm 1.20$ & $5.11 \pm 0.22$ & $3.65 \pm 0.13$ & $4.26 \pm 0.29$ \\
digested feed (\%) & & & & & \\
\hline
\end{tabular}

The proportion of feed converted into larval biomass, feed used for metabolism, and feed residue for each ratio of blended mediums for BSFL feeding are shown in Figure 3. The increase in feed residue when fed BSFL with G1 to G3 could be ascribed to the insufficient nutrients presented in blended sewage sludge that afflicted the palatability of BSFL. The presence of only sewage sludge in the G1 medium would cause the BSFL to prioritize the allocated energy budget in its body to maintain homeostasis by increasing metabolism of consumed feed, reducing excretion, and increasing the amount of consumed feed, leading to a lower amount of feed residue as opposed to the G2 and G3 mediums [15]. The further increase in PKE in the G2 and G3 mediums led to the higher amount of feed nutrition than required for larval growth. Thus, the feed was left over as a feed residue [15]. However, the feed residue then decreased when employing the G4, G5 and control mediums. This could be due to the imbalance of nutrition in blended feed, resulting in higher metabolism of consumed feed for these mediums. The observation was in conformity with the discussion provided for the final larval weight parameter in the presence of excess lipid and protein from PKE (Figure 2). 


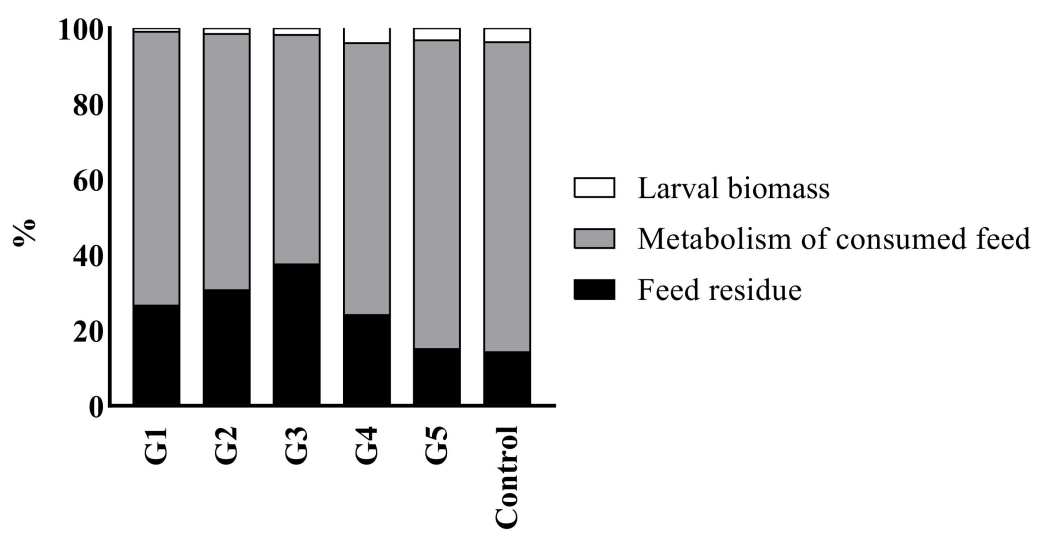

Figure 3. Proportion of feed converted into larval biomass, feed used for metabolism, and feed residue for each ratio of blended sewage sludge employed for BSFL rearing.

\subsection{Effect of Different Ratios of Blended Sewage Sludge on BSFL Lipid Yield}

The lipid yields from BSFL fed with various blended sewage sludge ratios are shown in Figure 4. The BSFL fed with sewage sludge only offered a lipid yield of merely $8.61 \pm$ $0.18 \%$. The values of lipid yield increased from $8.61 \pm 0.18 \%$ to $12.81 \pm 0.00 \%$ when the PKE was added into the sewage sludge and reached the highest at $17 \pm 1.77 \%$ when fed with sewage sludge to PKE at a ratio of 3:2 in the G3 medium. The higher larval weight resulted in higher level of lipid yield [42]. However, the further increase in PKE caused the decrease in BSFL lipid yield due to the presence of more non-fiber carbohydrate (NFC) composition. The highest larval weight was obtained with the G4 medium, while the highest lipid yield was with the G3 medium. Apart from the effect of larval weight on lipid yield, the NFC content in feed was also considered as a factor that affected the larval lipid yield. The NFC content decreased once the proportion of PKE was increased [59]. As NFC content would affect the lipid accumulation in the larval body, the lower NFC level led to a lower lipid yield as reported by Danieli et al., (2019) [60] since carbohydrates would be converted into lipids in the larval body [39]. Hence, the appropriate protein and NFC composition in feed should be considered, as the protein supply played a significant role in larval weight and lipid yield. Nevertheless, the higher protein and lower NFC condition also led to lower lipid yields from harvested BSFL biomass [39].

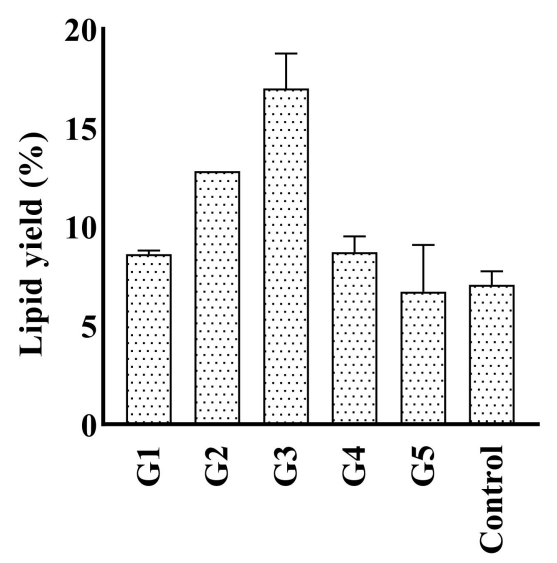

Figure 4. Lipid yields from BSFL fed with different ratios of blended sewage sludge.

\subsection{BSFL-Based Biodiesel}

The FAME profiles derived from larval lipids fed with various ratios of blended sewage sludge are presented in Table 2 . The composition in feed mediums would affect the FAME compositions and subsequently the biodiesel qualities [9,61]. In this study, the highest percentage component in the FAME mixture was C12:0, followed by C18:1, C14:0, 
and C16:0. The quantity of $\mathrm{C} 12: 0$ and $\mathrm{C} 18: 1$ contents corresponded with the presence of PKE, i.e., C12:0 content increased with higher PKE proportions and reached the highest in G3 before decreasing with further increase in PKE, while C18:1 decreased once PKE was added in feed.

Table 2. Percentage of FAME content of BSFL-derived biodiesel fed with various ratio of blended sewage sludge.

\begin{tabular}{ccccccc}
\hline \multirow{2}{*}{ FAMEs } & \multicolumn{7}{c}{ Blended Sewage Sludge } \\
\cline { 2 - 7 } & G1 & G2 & G3 & G4 & G5 & Control \\
\hline C10:0 & 0.86 & 5.56 & 4.48 & 18.90 & 16.35 & 5.73 \\
C12:0 & 19.56 & 24.28 & 53.36 & 21.37 & 7.91 & 16.92 \\
C14:0 & 10.26 & 16.35 & 12.52 & 6.62 & 16.06 & 11.01 \\
C14:1 & 8.93 & 7.18 & 2.79 & 14.15 & 7.85 & 16.11 \\
C16:0 & 15.34 & 10.24 & 9.89 & 16.13 & 11.93 & 5.28 \\
C16:1 & 12.83 & 1.37 & 4.40 & 6.26 & 5.24 & 5.46 \\
C18:0 & - & 2.56 & 1.23 & 8.67 & 5.82 & 10.30 \\
C18:1 & 24.37 & 20.29 & 9.22 & 5.0 & 18.56 & 11.91 \\
C18:2 & 7.86 & 12.17 & 2.11 & 2.89 & 10.30 & 17.28 \\
\hline
\end{tabular}

Another point to notice was that the BSFL-derived biodiesel fed with various ratios of blended sewage sludge offered an essential composition to produce high quality of biodiesel. The FAME profiles revealed the dominating content of saturated fatty acid (SFA) and low in polyunsaturated fatty acid (PUFA) as shown in Figure 5 [62]. The content of SFA also provided a similar pattern of lipid yield and C12:0, i.e., the highest SFA content was obtained in G3, which was $81.48 \%$ before the percentage of SFA dropped with the increase in PKE proportion. The FAME profile could be ascribed to the effect of larval weight and NFC content in feeding substrate on FAME composition, since a larger larval weight would lead to more accumulation of C12:0 and SFA. However, the further increase in PKE would reduce the NPC content, which influenced the C12:0 component as BSFL would synthesize C12:0 from carbohydrates presented in feed as reported by Ewald et al. (2020). The high SFA and low PUFA contents could lower a cold plugging point that affects cold flow properties. Nonetheless, the higher molecular weight of FAMEs would increase viscosity and density, and the performance of oxidative stability was good for a better storability of biodiesel [42,61-64]. Hence, the optimum proportion of blended sewage sludge should be considered to determine the optimum proportion of SFA and PUFA for producing a good quality biodiesel. Furthermore, biodiesel with a high SFA level indicates a higher cetane number than biodiesel with a high level of unsaturated fatty acid, i.e., better fuel combustion inside a compression engine [65].

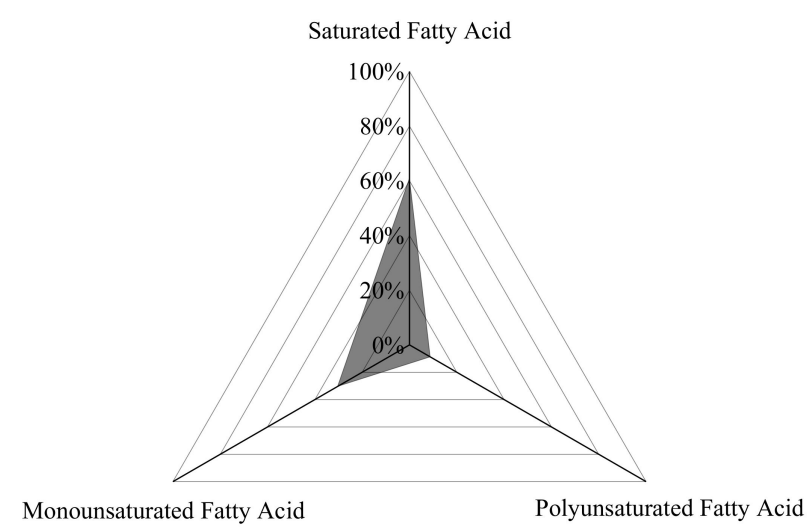

Figure 5. Degree of unsaturation of fatty acid methyl esters (FAMEs) profile in BSFL-based biodiesel fed with various ratios of blended sewage sludge. 


\subsection{Projection for Large-Scale Production of BSFL-Based Biodiesel}

With regard to the worthiness of valorizing blended sewage sludge by BSFL for the subsequent projection to industrial scale, the economical calculations were estimated based on lab-scale data whilst using discounted cash flow and benefit per cost analysis. For an industrial scale, the calculations can be generally divided into 4 parts: namely, (1) investment cost, (2) operating cost, (3) transportation cost, and (4) product cost, i.e., biodiesel cost. First, the investment cost encompasses installation and equipment cost, and this expense is usually incurred once, such as industrial reactor plants. Next, the operating cost which will be expensed annually is calculated from electricity, chemicals, water system, and other utilities used in the plant. The transportation cost $(\mathrm{T})$ will mainly depend on the distance between the sewage sludge and PKE collection points and the BSFL-based biodiesel processing line $(\mathrm{D})$, the number of loads $(\mathrm{N})$, and the rate of the truck $(\mathrm{r})$ as shown in Equation (6) [66]. Finally, the product cost, i.e., biodiesel in this case, is influenced by the feedstock cost, plant size, and value of glycerin by-product. Both the sewage sludge and PKE employed in the current study for feeding of BSFL were considered economical feedstock, since those are organic wastes generated abundantly from wastewater treatment plants and palm oil mills, respectively [67]. Moreover, the BSFL used as mediator is also cost-favorable since this species is abundant in tropical regions, and the larval rearing process is not complex [28].

$$
\mathrm{T}=\mathrm{DNr}
$$

The estimation would be based on the calculations that focused on feedstock, chemicals, and main product (biodiesel) prices for the present study. Indeed, the worthiness investigation for larval biodiesel production should also cover the calculations of the whole industrial scale that can be simulated using ASPEN PLUS software [68]. Furthermore, both investment and transportation costs could not be precisely determined in this study, since the investment cost depends on each plant, and transportation cost will be calculated based on the agreement between plant and transporter [66]. In the case of product cost, the biodiesel price would be calculated based on B7 (7\% blended biodiesel) price since this is a current biodiesel mandate in Malaysia's industrial scale [69]. Accordingly, Malaysia has six refineries with a production capacity of approximately 596,700 barrels per day. In this study, it was assumed that the production of biodiesel was 99,450 barrels per day per plant, i.e., $15,811,286 \mathrm{~L}$ per day per plant [70]. The biodiesel price is based on palm methyl ester price at fuel station which was about 2.28 MYR/liter or $0.56 \mathrm{USD} /$ liter [71]. Thus, the biodiesel could be produced about 5534 million liters per year and the revenue from biodiesel was around 3099 million USD/year. Those values were calculated with the assumption that the plant starts running after 15 days, since the BSFL offered the highest yield with G3 blended sewage sludge with 15 days of rearing. The process was also assumed to be running every day of the year with no shutdown. As the highest lipid yield in this study was $17 \%$ while employing the G3 medium, the quantity of sewage sludge and PKE used as a feedstock were 18,340,162 and 12,226,774 tons/year, respectively. Even though the sewage sludge was assumed to have no cost, in fact, the storage tank or transportation costs of sewage sludge are usually needed; while PKE was priced at about 119 USD/metric ton. Hence, the feedstock price was estimated at around 1320 million USD/year. In addition, the chemicals costs used for lipid extraction and transesterification processes, namely, petroleum ether, chloroform, $1 \mathrm{wt} \% \mathrm{KOH} / \mathrm{MeOH}$, and $10 \% \mathrm{NaCl} / \mathrm{MeOH}$, were obtained based on the prices by KSFE Company. In this regard, the estimated total cost of chemicals expense annually was around 78,623 million USD. Even though the BSFL-based biodiesel rendered a good quality of biodiesel, the lipid yield was still low, leading to unprofitable cost, with a benefit per cost ratio of less than 1.0. As the operating cost was significantly spent on chemicals, and $90 \%$ of total cost was incurred by the feedstock, our research used organic waste which was considered an inexpensive feedstock cost. Thus, once the industrial grade chemicals could be precisely determined with improvement on large-scale extraction and transesterification processes, investment in BSFL feedstock should be an interesting alternative to produce biodiesel [72]. In addition, in terms of environmental values, biodiesel can emit 
$\mathrm{CO}_{2}$ content, particulate matters, carbon monoxide, and hydrocarbons to a lesser extent than combustion of diesel fuel, which contributes to the reduction of total impact cost of particulates [73]. Currently, the lipid extraction method, which influences biodiesel quality used on a large scale, is still scarce. However, the supercritical carbon dioxide extraction method seems to be a suitable method for lipid extraction in upscaling industries at the moment, as this method leaves less effects on environment, i.e., emitting less $\mathrm{CO}_{2}$, and the residual biomass can be used for agricultural application [74]. The alkali-catalyzed transesterification to convert lipid into biodiesel and alkyl oxide solutions of sodium methoxide or potassium methoxide in methanol was confirmed as the most widely used for large continuous-flow production processes [72,75].

\section{Conclusions}

Black soldier fly larvae (BSFL) had a potential for valorizing blended sewage sludge and converting into valuable larval biomass through biotransformation process. The feed composition had been found to significantly affect larval growth, lipid yield, and fatty acid methyl esters (FAME) composition. The addition of palm kernel expeller (PKE) could enhance larval growth and biomass weight due to the presence of more protein and lipid content in feed. However, excess PKE content could negatively affect larval rearing since too high an energy and fiber content would retard larval growth. Furthermore, the larval weight would affect the lipid yield and FAME profile. Nevertheless, the proper proportion of sewage sludge and PKE should be considered, as excess PKE composition would lower the non-fiber carbohydrate content in feed, contributing to lesser lipid yield and FAME content. In this study, the optimum ratio of sewage sludge to PKE was obtained at 3:2, to provide the highest lipid yield and FAME content. Moreover, the FAME profile presented a significant composition that resulted in a good quality of biodiesel. Hence, the BSFL fed with blended sewage sludge had a potential to serve as the feedstock for producing biodiesel. However, the improvement of feeding substrate should be further investigated to enhance the quantity of lipid yield and FAME content.

Author Contributions: Conceptualization, R.R. and J.W.L.; methodology, R.R.; validation, K.K. and W.K.; formal analysis, R.R.; investigation, R.R.; resources, M.K.L. and Y.C.H.; data curation, R.R. and C.Y.W.; writing—original draft preparation, R.R.; writing—review and editing, K.K., W.K. and J.W.L.; visualization, W.D.O. and IW.K.S.; supervision, J.W.L. and W.K.; project administration, R.R. and K.K.; funding acquisition, K.K. and J.W.L. All authors have read and agreed to the published version of the manuscript.

Funding: The financial support from Yayasan Universiti Teknologi PETRONAS via YUTP-FRG, Research Collaboration Grant UTP-UMP-UMT-UCTS with the cost center of 015MD0-019, Universitas Islam Riau, Indonesia via International Grant with the cost center of 015ME0-164 and Universitas Pertamina, Indonesia via International Grant with the cost center of 015ME0-196 are gratefully acknowledged. The analysis and facility support from Silpakorn University are as well truly appreciated. Additionally, the authors thank United Fleet Palms Sdn. Bhd. for providing palm kernel expeller.

Acknowledgments: Kunlanan Kiatkittipong wishes to thank the financial support received from the Faculty of Engineering, King Mongkut's Institute of Technology Ladkrabang (Grant No. 2564-02-01-003).

Conflicts of Interest: The authors declare no conflict of interest.

\section{References}

1. Souza, M.C.G.; De Oliveira, M.F.; Vieira, A.T.; De Faria, A.M.; Batista, A.C.F. Methylic and ethylic biodiesel production from crambe oil (Crambe abyssinica): New aspects for yield and oxidative stability. Renew. Energy 2021, 163, 368-374. [CrossRef]

2. Teixeira, M.C.; Taouil, D.S.G. Biodiesel: Uma energia alternativa e verde. Vértices 2010, 12, 17-40. [CrossRef]

3. The Sources and Solutions: Fossil Fuels. 4 February 2019. Available online: https://www.epa.gov / nutrientpollution/sourcesand-solutions-fossil-fuels (accessed on 13 December 2020).

4. Production Statistics. 5 November 2018. Available online: https:/ / www.biodiesel.org/production/production-statistics (accessed on 20 September 2020). 
5. World Biodiesel Consumption by Country. 6 March 2009. Available online: https://www.indexmundi.com/energy/?product= biodiesel\&graph=consumption\&display=rank (accessed on 20 September 2020).

6. Sindhu, R.; Binod, P.; Pandey, A. Biological pretreatment of lignocellulosic biomass-An overview. Bioresour. Technol. 2016, 199, 76-82. [CrossRef] [PubMed]

7. Singh, R.; Prakash, A.; Balagurumurthy, B.; Bhaskar, T. Hydrothermal Liquefaction of Biomass. In Recent Advances in ThermoChemical Conversion of Biomass; Elsevier: Amsterdam, The Netherlands, 2015; pp. 269-291.

8. Meng, X.; Yang, J.; Xu, X.; Zhang, L.; Nie, Q.; Xian, M. Biodiesel production from oleaginous microorganisms. Renew. Energy 2009, 34, 1-5. [CrossRef]

9. Mohd-Noor, S.-N.; Wong, C.-Y.; Wong, K.C.; Mah-Hussin, M.-I.-A.; Uemura, Y.; Lam, M.-K.; Ramli, A.; Bashir, M.J.; Tham, L. Optimization of self-fermented period of waste coconut endosperm destined to feed black soldier fly larvae in enhancing the lipid and protein yields. Renew. Energy 2017, 111, 646-654. [CrossRef]

10. Wang, H.; Rehman, K.U.; Liu, X.; Yang, Q.; Zheng, L.; Li, W.; Cai, M.; Li, Q.; Zhang, J.; Yu, Z. Insect biorefinery: A green approach for conversion of crop residues into biodiesel and protein. Biotechnol. Biofuels 2017, 10, 304. [CrossRef]

11. Li, Q.; Zheng, L.; Hou, Y.; Yang, S.; Yu, Z. Insect fat, a promising resource for biodiesel. J. Pet. Environl. Biotechnol. $2011,2,2-6$.

12. Xu, F.; Sun, J.; Konda, N.V.S.N.M.; Shi, J.; Dutta, T.; Scown, C.D.; Simmons, B.A.; Singh, S. Transforming biomass conversion with ionic liquids: Process intensification and the development of a high-gravity, one-pot process for the production of cellulosic ethanol. Energy Environ. Sci. 2015, 9, 1042-1049. [CrossRef]

13. Abduh, M.Y.; Manurung, R.; Faustina, A.; Affanda, E.; Siregar, I.R.H. Bioconversion of pandanus tectorius using black soldier fly larvae for the production of edible oil and protein-rich biomass. J. Entomol. Zool Stud. 2017, 5, 803-809.

14. Shumo, M.; Osuga, I.M.; Khamis, F.M.; Tanga, C.M.; Fiaboe, K.K.M.; Subramanian, S.; Ekesi, S.; Van Huis, A.; Borgemeister, C. The nutritive value of black soldier fly larvae reared on common organic waste streams in Kenya. Sci. Rep. 2019, 9, 10110. [CrossRef]

15. Kinasih, I.; Putra, R.E.; Permana, A.D.; Gusmara, F.F.; Nurhadi, M.Y.; Anitasari, R.A. Growth performance of black soldier fly larvae (Hermetia illucens) fed on some plant based organic wastes. Hayati 2018, 25, 79.

16. Spranghers, T.; Ottoboni, M.; Klootwijk, C.; Ovyn, A.; Deboosere, S.; De Meulenaer, B.; Michiels, J.; Eeckhout, M.; De Clercq, P.; De Smet, S. Nutritional composition of black soldier fly (Hermetia illucens) prepupae reared on different organic waste substrates. J. Sci. Food Agric. 2017, 97, 2594-2600. [CrossRef] [PubMed]

17. Lalander, C.; Diener, S.; Zurbrügg, C.; Vinnerås, B. Effects of feedstock on larval development and process efficiency in waste treatment with black soldier fly (Hermetia illucens). J. Clean. Prod. 2019, 208, 211-219. [CrossRef]

18. Manzano-Agugliaro, F.; Sánchez-Muros, M.J.; Barroso, F.G.; Sánchez, A.I.M.; Pérez-Ben, C.; Pérez-Bañòn, C. Insects for biodiesel production. Renew. Sustain. Energy Rev. 2012, 16, 3744-3753. [CrossRef]

19. Yang, S.; Li, Q.; Zeng, Q.; Zhang, J.; Yu, Z.; Liu, Z. Conversion of Solid Organic Wastes into Oil via Boettcherisca peregrine (Diptera: Sarcophagidae) Larvae and Optimization of Parameters for Biodiesel Production. PLoS ONE 2012, 7, e45940. [CrossRef]

20. Leung, D.; Yang, D.; Li, Z.; Zhao, Z.; Chen, J.; Zhu, L. Biodiesel from Zophobas morio Larva Oil: Process Optimization and FAME Characterization. Ind. Eng. Chem. Res. 2011, 51, 1036-1040. [CrossRef]

21. Yang, S.; Liu, Z. Pilot-scale biodegradation of swine manure via Chrysomya megacephala (Fabricius) for biodiesel production. Appl. Energy 2014, 113, 385-391. [CrossRef]

22. Bowling, J.J.; Anderson, J.B.; Armbrust, K.L.; Hamann, M.T. Evaluation of potential biodiesel feedstock production from oleaginous insect Solenopsis sp. Fuel 2014, 117, 5-7. [CrossRef]

23. Zheng, L.; Hou, Y.; Li, W.; Yang, S.; Li, Q.; Yu, Z. Exploring the potential of grease from yellow mealworm beetle (Tenebrio molitor) as a novel biodiesel feedstock. Appl. Energy 2013, 101, 618-621. [CrossRef]

24. Yang, S.; Li, Q.; Gao, Y.; Zheng, L.; Liu, Z. Biodiesel production from swine manure via housefly larvae (Musca domestica L.). Renew. Energy 2014, 66, 222-227. [CrossRef]

25. Li, Q.; Zheng, L.; Cai, H.; Garza, E.; Yu, Z.; Zhou, S. From organic waste to biodiesel: Black soldier fly, Hermetia illucens, makes it feasible. Fuel 2011, 90, 1545-1548. [CrossRef]

26. Nguyen, T.T.; Tomberlin, J.K.; VanLaerhoven, S. Influence of Resources on Hermetia illucens (Diptera: Stratiomyidae) Larval Development. J. Med. Èntomol. 2013, 50, 898-906. [CrossRef] [PubMed]

27. Diener, S.; Lalander, C.; Zurbrügg, C.; Vinnerås, B. In Opportunities and constraints for medium-scale organic waste treatment with fly larvae composting. In Proceedings of the 15th International Waste Management and Landfill Symposium, Cagliari, Sardinia, Italy, 5-9 October 2015; pp. 5-9.

28. Caruso, D.; Devic, E.; Subamia, I.; Talamond, P.; Baras, E. Technical Handbook of Domestication and Production of Diptera Black Soldier Fly (bsf), Hermetia illucens, Stratiomyidae; PT Penerbit IPB Press, Kampus IPB Taman Kencana: Bogor, Indonesia, 2014.

29. Ushakova, N.A.; Brodskii, E.S.; Kovalenko, A.A.; Bastrakov, A.I.; Kozlova, A.A.; Pavlov, D.S. Characteristics of lipid fractions of larvae of the black soldier fly Hermetia illucens. Dokl. Biochem. Biophys. 2016, 468, 209-212. [CrossRef] [PubMed]

30. Chen, Y.-H.; Chen, J.-H.; Luo, Y.-M. Complementary biodiesel combination from Tung and medium-chain fatty acid oils. Renew. Energy 2012, 44, 305-310. [CrossRef]

31. Leong, S.Y.; Kutty, S.R.M.; Malakahmad, A.; Tan, C.K. Feasibility study of biodiesel production using lipids of Hermetia illucens larva fed with organic waste. Waste Manag. 2016, 47, 84-90. [CrossRef] [PubMed]

32. Hanum, F.; Yuan, L.C.; Kamahara, H.; Aziz, H.A.; Atsuta, Y.; Yamada, T.; Daimon, H. Treatment of Sewage Sludge Using Anaerobic Digestion in Malaysia: Current State and Challenges. Front. Energy Res. 2019, 7, 19. [CrossRef] 
33. Singh, R.; Agrawal, M. Potential benefits and risks of land application of sewage sludge. Waste Manag. 2008, 28, 347-358. [CrossRef] [PubMed]

34. Aydin, S.; Tor, A.; Aydin, M.E. Investigation on the Levels of Heavy Metals, Polycyclic Aromatic Hydrocarbons, and Polychlorinated Biphenyls in Sewage Sludge Samples and Ecotoxicological Testing. CLEAN Soil Air Water 2013, 41, 411-418. [CrossRef]

35. Zhang, X.; Wang, X.-Q.; Wang, D.-F. Immobilization of Heavy Metals in Sewage Sludge during Land Application Process in China: A Review. Sustainability 2017, 9, 2020. [CrossRef]

36. Fytili, D.; Zabaniotou, A. Utilization of sewage sludge in EU application of old and new methods-A review. Renew. Sustain. Energy Rev. 2008, 12, 116-140. [CrossRef]

37. Popa, R.; Green, T.R. Using black soldier fly larvae for processing organic leachates. J. Econ. Èntomol. 2012, 105, 374-378. [CrossRef] [PubMed]

38. Diener, S.; Zurbrugg, C.; Tockner, K. Bioaccumulation of heavy metals in the black soldier fly, Hermetia illucens and effects on its life cycle. J. Insects Food Feed. 2015, 1, 261-270. [CrossRef]

39. Gold, M.; Cassar, C.M.; Zurbrügg, C.; Kreuzer, M.; Boulos, S.; Diener, S.; Mathys, A. Biowaste treatment with black soldier fly larvae: Increasing performance through the formulation of biowastes based on protein and carbohydrates. Waste Manag. 2020, 102, 319-329. [CrossRef] [PubMed]

40. Wong, C.Y.; Aris, M.N.M.; Daud, H.; Lam, M.K.; Yong, C.S.; Abu Hasan, H.; Siewhui, C.; Show, P.L.; Hajoeningtijas, O.D.; Ho, Y.-C.; et al. In-Situ Yeast Fermentation to Enhance Bioconversion of Coconut Endosperm Waste into Larval Biomass of Hermetia illucens: Statistical Augmentation of Larval Lipid Content. Sustainability 2020, 12, 1558. [CrossRef]

41. Sheng, G.-P.; Yu, H.-Q.; Li, X.-Y. Extracellular polymeric substances (EPS) of microbial aggregates in biological wastewater treatment systems: A review. Biotechnol. Adv. 2010, 28, 882-894. [CrossRef]

42. Wong, K.C.; Mohd-Noor, S.-N.; Wong, C.-Y.; Lam, M.-K.; Goh, P.-S.; Beniers, J.; Da Oh, W.; Jumbri, K.; Ghani, N.A. Palatability of black soldier fly larvae in valorizing mixed waste coconut endosperm and soybean curd residue into larval lipid and protein sources. J. Environ. Manag. 2019, 231, 129-136. [CrossRef]

43. Anjum, M.; Khalid, A.; Mahmood, T.; Aziz, I. Anaerobic co-digestion of catering waste with partially pretreated lignocellulosic crop residues. J. Clean. Prod. 2016, 117, 56-63. [CrossRef]

44. Li, R.; Chen, S.; Li, X.; Lar, J.S.; He, Y.; Zhu, B. Anaerobic Codigestion of Kitchen Waste with Cattle Manure for Biogas Production. Energy Fuels 2009, 23, 2225-2228. [CrossRef]

45. Siew, W. Characteristics and uses of Malaysian palm kernel cake. PORIM Technol. 1989, 14, 2-3.

46. Tschirner, M.; Simon, A. Influence of different growing substrates and processing on the nutrient composition of black soldier fly larvae destined for animal feed. J. Insects Food Feed. 2015, 1, 249-259. [CrossRef]

47. Ziegler, R. Biochemie und stoffwechsel. In Lehrbuch der Entomologie; Springer: Berlin/Heidelberg, Germany, $2010 ;$ pp. 75-89.

48. Sue, T.T. Quality and characteristics of Malaysian palm kernel cakes/expellers. Palm Oil Dev. 2004, 34, 1-3.

49. Brouwer, E. Report of sub-committee on constants and factors. In Proceedings of the 3rd Symposium on Energy Metabolism of Farm Animals; European Association for Animal Production: Rome, Italy; Academic Press: London, UK, 1965; pp. 441-443.

50. Dias, F.N. Supplementation of Palm Kernel Expeller to Grazing Dairy Farms in New Zealand: A Thesis Presented in Partial Fulfilment of the Requirements for the Degree of Doctor of Philosophy in Animal Science at Massey University, Palmerston North, New Zealand. Ph.D. Thesis, Massey University, Palmerston North, New Zealand, 2010.

51. Palmquist, D.L. Use of fats in diets for lactating dairy cows. In Proceedings of the Fats in Animal Nutrition; Elsevier: Amsterdam, The Netherlands, 1984; pp. 357-381.

52. Supriyatna, A.; Manurung, R.; Esyanti, R.R.; Putra, R.E. Growth of black soldier larvae fed on cassava peel wastes, an agriculture waste. J. Entomol. Zool Stud. 2016, 4, 161-165.

53. Nijhout, H.F. Physiological Control of Molting in Insects. Am. Zool. 1981, 21, 631-640. [CrossRef]

54. Nijhout, H.F.; Williams, C.M. Control of moulting and metamorphosis in the tobacco hornworm, Manduca sexta (L.): Growth of the last-instar larva and the decision to pupate. J. Exp. Biol. 1974, 61, 481-491. [PubMed]

55. Riddiford, L.M.; Truman, J.W. Hormone Receptors and the Regulation of Insect Metamorphosis. Am. Zool. 1993, 33, 340-347. [CrossRef]

56. Suzuki, Y.J.; Koyama, T.; Hiruma, K.; Riddiford, L.M.; Truman, J.W. A molt timer is involved in the metamorphic molt in Manduca sexta larvae. Proc. Proc. Natl. Acad. Sci. USA 2013, 110, 12518-12525. [CrossRef] [PubMed]

57. Bennett, G. Is There a Specific Appetite for Protein? CRC Press LLC: Boca Raton, FL, USA, 2000.

58. Bentancourt, C.M.; Scatoni, I.B.; González, Á; Franco, J. Effects of larval diet on the development and reproduction of Argyrotaenia sphaleropa (Meyrick) (Lepidoptera: Tortricidae). Neotrop. Èntomol. 2003, 32, 551-557. [CrossRef]

59. Van Wyngaard, J.; Meeske, R. Palm kernel expeller increases milk fat content when fed to grazing dairy cows. South Afr. J. Anim. Sci. 2017, 47, 219. [CrossRef]

60. Danieli, P.P.; Lussiana, C.; Gasco, L.; Amici, A.; Ronchi, B. The Effects of Diet Formulation on the Yield, Proximate Composition, and Fatty Acid Profile of the Black Soldier Fly (Hermetia illucens L.) Prepupae Intended for Animal Feed. Animals 2019, 9, 178. [CrossRef]

61. Ramos, M.J.; Fernández, C.M.; Casas, A.; Rodríguez, L.; Pérez, Á. Influence of fatty acid composition of raw materials on biodiesel properties. Bioresour. Technol. 2009, 100, 261-268. [CrossRef]

62. Surendra, K.; Olivier, R.; Tomberlin, J.K.; Jha, R.; Khanal, S.K. Bioconversion of organic wastes into biodiesel and animal feed via insect farming. Renew. Energy 2016, 98, 197-202. [CrossRef] 
63. Ewald, N.; Vidakovic, A.; Langeland, M.; Kiessling, A.; Sampels, S.; Lalander, C. Fatty acid composition of black soldier fly larvae (Hermetia illucens)_Possibilities and limitations for modification through diet. Waste Manag. 2020, 102, 40-47. [CrossRef] [PubMed]

64. Sulaiman, S.; Aziz, A.A.; Aroua, M.K. Reactive extraction of solid coconut waste to produce biodiesel. J. Taiwan Inst. Chem. Eng. 2013, 44, 233-238. [CrossRef]

65. Biodiesel Fuel Quality. 3 April 2019. Available online: https://farm-energy.extension.org/biodiesel-fuel-quality/\#: \{\}:text= Biodiesel\%20usually\%20has\%20a\%20higher, than\%20biodiesel\%20from\%20unsaturated\%20oil (accessed on 13 December 2020).

66. Tesfamariam, E.H.; Ogbazghi, Z.M.; Annandale, J.G.; Gebrehiwot, Y. Cost-Benefit Analysis of Municipal Sludge as a Low-Grade Nutrient Source: A Case Study from South Africa. Sustainability 2020, 12, 9950. [CrossRef]

67. Grobelak, A.; Czerwińska, K.; Murtaś, A. General considerations on sludge disposal, industrial and municipal sludge. Ind. Munic. Sludge 2019, 135-153. [CrossRef]

68. You, Y.-D.; Shie, J.-L.; Chang, C.-Y.; Huang, S.-H.; Pai, C.-Y.; Yu, Y.-H.; Chang, C.H. Economic Cost Analysis of Biodiesel Production: Case in Soybean Oil. Energy Fuels 2008, 22, 182-189. [CrossRef]

69. Zulqarnain; Yusoff, M.H.M.; Ayoub, M.; Jusoh, N.; Abdullah, A.Z. The Challenges of a Biodiesel Implementation Program in Malaysia. Processes 2020, 8, 1244. [CrossRef]

70. Yusoff, M.N.A.M.; Zulkifli, N.W.M.; Sukiman, N.L.; Chyuan, O.H.; Hassan, M.H.; Hasnul, M.H.; Zulkifli, M.S.A.; Abbas, M.M.; Zakaria, M.Z. Sustainability of Palm Biodiesel in Transportation: A Review on Biofuel Standard, Policy and International Collaboration between Malaysia and Colombia. Bioenergy Res. 2020, 1-18. [CrossRef]

71. Ching, O.T. Cheaper to Use Biodiesel Now. 31 October 2018. Available online: https://www.nst.com.my/business/2018/10/42 6997 / cheaper-use-biodiesel-now (accessed on 22 January 2021).

72. Özçimen, D.; Yucel, S. Novel methods in biodiesel production. Marco Aurélio Santos Bernardes Biofuel's Eng. Process Technol. 2011, 1, 353-384.

73. Duncan, J. Costs of biodiesel production. Energy Effic. Conserv. Auth. 2003.

74. Moradi-Kheibari, N.; Ahmadzadeh, H.; Talebi, A.F.; Hosseini, M.; Murry, M.A. Recent Advances in Lipid Extraction for Biodiesel Production. In Advances in Feedstock Conversion Technologies for Alternative Fuels and Bioproducts; Elsevier: Amsterdam, The Netherlands, 2019; pp. 179-198.

75. Singh, A.; He, B.; Thompson, J.; Van Gerpen, J. Process optimization of biodiesel production using alkaline catalysts. Appl. Eng. Agric. 2006, 22, 597-600. [CrossRef] 